\title{
Diversities of antimicrobial resistance patterns across Staphylococcus aureus and Coagulase-Negative Staphylococci isolated from dairy herbs in Jiangsu province, China
}

Weijie Jin ( $\square$ wenjiejin1@yzu.edu.cn )

Yangzhou University https://orcid.org/0000-0003-4895-1166

Weidong Lin

Yangzhou University

Qing Feng

Yangzhou University

Dashuai Zhang

Yangzhou University

Juan Yang

Yangzhou University

Aijian Qin

Yangzhou University

Research article

Keywords: Mastitis, Staphylococcus aureus (SA), Coagulase-Negative Staphylococci (CNS), Antimicrobial resistance, Resistance pattern, Resistance genes

Posted Date: October 28th, 2020

DOI: https://doi.org/10.21203/rs.3.rs-80176/v1

License: (c) (i) This work is licensed under a Creative Commons Attribution 4.0 International License. Read Full License 


\section{Abstract \\ Background}

As mastitis major causing agents, Coagulase-Negative Staphylococci (CNS) and Staphylococcus aureus (SA), are important and their connections are special and worth comparing. The overall aim of this study is to investigate antimicrobial resistance patterns of CNS and SA. Understanding the special characters of staphylococci is essential for finding the precise strategies or directions against them.

\section{Results}

Staphylococci (47.63\%) were the commonest pathogens in subclinical mastitis in Jiangsu province. $73.34 \%$ and $45.78 \%$ of CNS respectively were extensively drug-resistant (XDR) strains and multiple drug-resistant (MDR) strains, mainly resisting penicillin (77.78\%) and ceftazidime (55.95\%); for SA, $62.52 \%$ of them were MDR strains and resistant to penicillin (94.05\%) and norfloxacin (58.33\%). Notably, 4 CNS were pandrug-resistant (PDR) strains. According to the chi-square test results, we summary and find that SA was more resistant to quinolones (ciprofloxacin, levofloxacin, and norfloxacin) and co-trimoxazole antibiotics than CNS, significantly; on the other hand, CNS were significantly more resistant to lincomycins (clindamycin), macrolides (including erythromycin and clarithromycin), tetracycline, and nitrofurantoin antibiotics than $\mathrm{SA}_{\text {, }}$ in total. Resistance genes were detected more frequently in CNS than SA; nearly a third of CNS resit penicillin by $\beta$-lactamase coded by blaZ and CNS resist tetracycline mainly by protein pump mechanism. For $\mathrm{SA}, \mathrm{blaZ}$ was detected out $27.2 \%$, and the other five resistance genes were rare to be found.

\section{Conclusion}

Responding to antibiotics interfering with metabolisms of nucleotide, SA might be more resistant than CNS; while CNS strains are more likely to become mutations to survive under the stress of antibiotics interfering with protein synthesis. These might provide the advantages for CNS to represent like a reservoir of resistance genes for other staphylococci as the previous researches' assumption.

\section{Background}

Staphylococci have been considered the most commonly isolated bacteria from from bovine mammary secretions [1, 2]; bovine mammary is a common disease in dairy herds and milk from dairy cows with mastitis represents a food issue; thus, it results in a huge economic burden to farms as well as public health problems [3].

Staphylococci are divided into coagulase-positive staphylococci (CPS) and coagulase-negative staphylococci (CNS) based on their ability to coagulate rabbit plasma. Staphylococcus aureus (SA), a member of CPS, has been regarded as the most pathogenic species [4], and a major pathogen in leading to bovine mastitis [5]. Other CPS, Staphylococcus intermedius and Staphylococcus hyicus, is rare to recover. Hence staphylococci also are often classified into SA and CNS. Classically, it had been considered sufficient because CNS seem only to cause subclinical or mild clinical mastitis and lack the ability to result in severe mastitis [6]; on the other hand, Cows with CNS intramammary infection exhibited a similar daily milk production when compared to culture-negative cows, and much higher daily milk production when compared to cows infected with major pathogens, like SA [7]. These findings are in line with previous observations where CNS infected cows also showed a moderate increase in somatic cell count (SCC) [8].

As mastitis major causing agents, staphylococci, SA and CNS are important in bovine mastitis and their connections are special and worth comparing. Yet, the ability of CNS resistance to various antimicrobials has been demonstrated [9]; Although SA causes more server mastitis than CNS, resistance to various antimicrobials is more common in CNS than in SA; the resistant-associated genes carried by CNS then can be transmitted by cohabitation with other pathogenic staphylococci [10]. Therefore, CNS may represent like a reservoir of resistance genes for other staphylococci like SA [11]; it has also found evidence of antibiotic 
resistance gene transfer among them [12]. Although some features of CNS and SA have been often reported separately [6, 8-10], the similarities and differences of their resistant models still are covered. Only after understanding the special characters of staphylococci, we can find the precise strategies and research directions to defeat them.

This study investigates whether CNS and SA share similar antimicrobial resistance patterns by analyzing both the phenotypic resistance results with the chi-square test and genotypic resistance results. Finally, the characters of their general resistance mechanisms and resistant patterns are provided.

\section{Results}

\subsection{The Staphylococci Panorama in subclinical Mastitis}

A total of $86.34 \%$ of the CMT-positive samples (544 of 630 ) were considered bacteriologically positive. Among the milk samples showing bacterial growth, staphylococci were the most commonly isolated bacterial group $(n=393 ; 47.63 \%$ of the total bacterial isolations) which included SA $(n=168 ; 20.36 \%)$ and CNS $(n=225 ; 27.27 \%)$, followed by Streptococcus $(n=237.28 .73 \%)$ and others $(n=195 ; 23.64 \%)$.

Our results confirmed the most of the CNS isolates were Staphylococcus sciuri $(\mathrm{n}=51)$ and Staphylococcus xylosus $(\mathrm{n}=$ 39), followed by Staphylococcus epidermidis $(n=32)$, Staphylococcus arlettae $(n=28)$, Staphylococcus chromogenes $(n=20)$, Staphylococcus haemolyticus $(\mathrm{n}=12)$, Staphylococcus simulans $(\mathrm{n}=11)$, Staphylococcus equorum $(\mathrm{n}=10)$, Staphylococcus saprophyticus $(n=7)$, Staphylococcus warneri $(n=6)$; and the lowest incidences were Staphylococcus succinus, Staphylococcus hyicus and Staphylococcus muscae ( $\mathrm{n}=3$ each).

\subsection{Phenotypic Antimicrobial Resistance Characteristics}

All staphylococci were evaluated for the susceptibility to 15 antimicrobials within nine categories, then the results of SA and CNS were compared by the chi-square testing (Table 1). The majority of staphylococci were sensitive to chloramphenicol, nitrofurantoin and clarithromycin, but showed resistance to penicillin, ceftazidime and norfloxacin. Chloramphenicol was also the most effective drug against CNS (86.67\%), but the highest proportion of SA is susceptible to clarithromycin (92.26\%).

Staphylococcus aureus were mainly resistant to penicillin (94.05\%), norfloxacin (58.33\%), levofloxacin (54.76\%), ciprofloxacin (57.74\%), ceftazidime(55.95\%), and co-trimoxazole(41.07\%). CNS were mainly resistant to penicillin (77.78\%) ceftazidime (55.95\%) tetracycline (36.89\%), and erythromycin (24.44\%). 
Table 1

Distribution of antibiotic susceptibility among staphylococci $(n=393)$ within CNS and SA

\begin{tabular}{|c|c|c|c|c|}
\hline \multirow[t]{2}{*}{ Antimicrobial agent } & \multicolumn{2}{|l|}{ Resistant } & \multicolumn{2}{|c|}{ Intermediate or Susceptible } \\
\hline & SA & CNS & SA & CNS \\
\hline Penicillin & $158(94.05 \%)^{a}$ & $175(77.78 \%)^{b}$ & $10(5.95 \%)^{a}$ & $50(22.22 \%)^{b}$ \\
\hline Ceftriaxone & $6(3.57 \%)^{\mathrm{a}}$ & $15(6.67 \%)^{a}$ & $162(96.43 \%)^{a}$ & $210(93.33 \%)^{a}$ \\
\hline Co-trimoxazole & $69(41.07 \%)^{a}$ & $26(11.56 \%)^{b}$ & $99(58.93 \%)^{a}$ & $199(88.44 \%)^{b}$ \\
\hline Erythromycin & $7(4.17 \%)^{\mathrm{a}}$ & $55(24.44 \%)^{\mathrm{b}}$ & $161(95.83 \%)^{a}$ & $170(75.66 \%)^{\mathrm{b}}$ \\
\hline Levofloxacin & $92(54.76 \%)^{a}$ & $29(12.89 \%)^{b}$ & $76(45.24 \%)^{a}$ & $196(87.11 \%)^{b}$ \\
\hline Clarithromycin & $5(2.98 \%)^{a}$ & $38(16.89 \%)^{b}$ & $163(97.02 \%)^{\mathrm{a}}$ & $187(83.11 \%)^{b}$ \\
\hline Tetracycline & $8(4.76 \%)^{a}$ & $83(36.89 \%)^{b}$ & $160(95.24 \%)^{a}$ & $142(63.11 \%)^{b}$ \\
\hline Norfloxacin & $98(58.33 \%)^{a}$ & $44(19.56 \%)^{\mathrm{b}}$ & $70(41.67 \%)^{a}$ & $181(80.44 \%)^{\mathrm{b}}$ \\
\hline Chloramphenicol & $18(10.71 \%)^{a}$ & $22(9.78 \%)^{a}$ & $150(89.29 \%)^{a}$ & $203(90.22 \%)^{a}$ \\
\hline Ciprofloxacin & $97(57.74 \%)^{a}$ & $34(15.11 \%)^{b}$ & $71(42.46 \%)^{a}$ & $191(84.89 \%)^{b}$ \\
\hline Cefotaxime & $1(0.60 \%)^{a}$ & $10(4.44 \%)^{\mathrm{a}}$ & $167(99.40 \%)^{a}$ & $215(95.56 \%)^{a}$ \\
\hline Ceftazidime & $94(55.95 \%)^{a}$ & $93(41.33 \%)^{b}$ & $74(44.05 \%)^{a}$ & $132(58.67 \%)^{b}$ \\
\hline Nitrofurantoin & $12(7.14 \%)^{a}$ & $31(13.78 \%)^{b}$ & $156(92.86 \%)^{a}$ & $194(86.22 \%)^{b}$ \\
\hline Minocycline & $5(2.98 \%)^{\mathrm{a}}$ & $13(5.78 \%)^{a}$ & $163(97.02 \%)^{a}$ & $212(94.22 \%)^{a}$ \\
\hline Clindamycin & $9(5.36 \%)^{a}$ & $30(13.33 \%)^{b}$ & $159(94.64 \%)^{a}$ & $195(86.67 \%)^{b}$ \\
\hline
\end{tabular}

According to the chi-square test results, it shows that SA was significantly better to resist antibiotics interfering in the metabolism of nucleotides than CNS; however, CNS strains were significantly better to resist antibiotics interfering in bacterial protein synthesis, except chloramphenicol which was forbidden to use in China.

Table $2 \& 3$ shows the panorama of multidrug resistance patterns of SA and CNS isolates in this study. For SA, $62.52 \%$ of them were multiple drug-resistant (MDR) resisting more than 3 antimicrobial categories. Staphylococcus aureus were mainly resistant to four antimicrobial categories, and the most common multidrug resistance patterns within them were resistant to $\beta$-lactamase, cephalosporin, quinolone, and sulfonamide antibiotics. 73.34\% Of CNS were extensively drug-resistant (XDR), which were resistant to $\geq 2$ antimicrobial categories, and $45.78 \%$ were MDR strains. CNS were often resistant to two antimicrobial categories; the most common multidrug resistance pattern within them was resistant to $\beta$-lactamase and lincomycin antibiotics. However, what is worth mentioning, there is 4 CNS were pandrug-resistant (PDR) bacteria which were non-susceptible to all antimicrobial agents listed in this study. 
Table 2

The prevalence of multidrug resistance among SA

\begin{tabular}{|c|c|c|c|c|c|c|c|}
\hline $\begin{array}{l}\text { No. of } \\
\text { classified of } \\
\text { antibiotics }\end{array}$ & $\begin{array}{l}\text { Multidrug } \\
\text { resistance } \\
\text { pattern }^{\mathrm{a}}\end{array}$ & $\begin{array}{l}\text { No of } \\
\text { isolates }\end{array}$ & $\begin{array}{l}\text { Resistant } \\
\text { rate(\%) }\end{array}$ & $\begin{array}{l}\text { No. of } \\
\text { classified of } \\
\text { antibiotics }\end{array}$ & $\begin{array}{l}\text { Multidrug } \\
\text { resistance pattern }\end{array}$ & $\begin{array}{l}\text { No of } \\
\text { isolates }\end{array}$ & $\begin{array}{l}\text { Resistant } \\
\text { rate(\%) }\end{array}$ \\
\hline \multirow[t]{6}{*}{3} & Lac + Qui + Sul & 22 & \multirow[t]{6}{*}{$17.26 \%$} & \multirow[t]{4}{*}{4} & Lac + Qui + Aph + Tet & 1 & \\
\hline & Lac + Lin + Tet & 2 & & & Lac + Qui + Tet + Sul & 1 & \\
\hline & $\begin{array}{l}\text { Lac + Qui + } \\
\text { Aph }\end{array}$ & 2 & & & $\mathrm{Lac}+\mathrm{Aph}+\mathrm{Nit}+\mathrm{Tet}$ & 1 & \\
\hline & Lac + Cep + Lin & 1 & & & Lin + Aph + Tet + Sul & 1 & \\
\hline & $\begin{array}{l}\mathrm{Lac}+\mathrm{Mac}+ \\
\mathrm{Lin}\end{array}$ & 1 & & \multirow[t]{7}{*}{5} & $\begin{array}{l}\text { Lac + Cep + Qui + Aph } \\
+ \text { Sul }\end{array}$ & 8 & $13.10 \%$ \\
\hline & $\mathrm{Lac}+\mathrm{Nit}+\mathrm{Tet}$ & 1 & & & $\begin{array}{l}\text { Lac + Cep + Lin + Qui } \\
\text { + Sul }\end{array}$ & 7 & \\
\hline \multirow[t]{11}{*}{4} & $\begin{array}{l}\text { Lac + Cep + } \\
\text { Qui + Sul }\end{array}$ & 22 & \multirow[t]{11}{*}{$27.98 \%$} & & $\begin{array}{l}\text { Lac + Cep + Qui + Nit } \\
+ \text { Sul }\end{array}$ & 2 & \\
\hline & $\begin{array}{l}\mathrm{Lac}+\mathrm{Qui}+\mathrm{Nit} \\
+\mathrm{Sul}\end{array}$ & 6 & & & $\begin{array}{l}\text { Lac + Lin + Qui + Nit + } \\
\text { Sul }\end{array}$ & 2 & \\
\hline & $\begin{array}{l}\text { Lac+ Lin + Qui } \\
+ \text { Sul }\end{array}$ & 5 & & & $\begin{array}{l}\text { Lac + Cep + Qui + Tet } \\
+ \text { Sul }\end{array}$ & 1 & \\
\hline & $\begin{array}{l}\text { Lac+Qui + } \\
\text { Aph + Sul }\end{array}$ & 3 & & & $\begin{array}{l}\mathrm{Lac}+\mathrm{Cep}+\mathrm{Mac}+ \\
\text { Qui + Sul }\end{array}$ & 1 & \\
\hline & $\begin{array}{l}\text { Lac + Cep + Nit } \\
+ \text { Tet }\end{array}$ & 1 & & & $\begin{array}{l}\text { Lac + Lin + Qui + Aph } \\
+ \text { Sul }\end{array}$ & 1 & \\
\hline & $\begin{array}{l}\mathrm{Lac}+\mathrm{Mac}+ \\
\mathrm{Lin}+\text { Qui }\end{array}$ & 1 & & \multirow[t]{4}{*}{6} & $\begin{array}{l}\text { Lac + Cep + Lin + Qui } \\
+ \text { Tet + Sul }\end{array}$ & 2 & \multirow[t]{4}{*}{$2.98 \%$} \\
\hline & $\begin{array}{l}\text { Lac + Mac + } \\
\text { Qui + Sul }\end{array}$ & 1 & & & $\begin{array}{l}\text { Lac + Cep + Mac + } \\
\text { Qui + Nit + Sul }\end{array}$ & 1 & \\
\hline & $\begin{array}{l}\mathrm{Lac}+\mathrm{Mac}+ \\
\text { Aph }+ \text { Tet }\end{array}$ & 1 & & & $\begin{array}{l}\text { Lac + Cep + Lin + Qui } \\
+ \text { Aph + Sul }\end{array}$ & 1 & \\
\hline & $\begin{array}{l}\mathrm{Lac}+\operatorname{Lin}+ \\
\text { Aph + Tet }\end{array}$ & 1 & & & $\begin{array}{l}\text { Lac + Lin + Qui + Aph } \\
+ \text { Tet + Sul }\end{array}$ & 1 & \\
\hline & $\begin{array}{l}\mathrm{Lac}+\mathrm{Lin}+ \\
\text { Aph }+ \text { Sul }\end{array}$ & 1 & & 7 & $\begin{array}{l}\text { Lac + Cep + Lin + Qui } \\
+ \text { Aph + Nit + Sul }\end{array}$ & 1 & $0.60 \%$ \\
\hline & $\begin{array}{l}\text { Lac + Lin + Nit } \\
+ \text { Tet }\end{array}$ & 1 & & 8 & $\begin{array}{l}\text { Lac + Cep + Mac + Lin } \\
+ \text { Qui + Nit + Tet + Sul }\end{array}$ & 1 & $0.60 \%$ \\
\hline
\end{tabular}


Table 3

The prevalence of multidrug resistance among CNS

\begin{tabular}{|c|c|c|c|c|c|c|c|}
\hline $\begin{array}{l}\text { No. of } \\
\text { antibiotics }\end{array}$ & $\begin{array}{l}\text { Multidrug } \\
\text { resistance } \\
\text { pattern }^{a}\end{array}$ & $\begin{array}{l}\text { No of } \\
\text { isolates }\end{array}$ & $\begin{array}{l}\text { Resistant } \\
\text { rate }(\%)\end{array}$ & $\begin{array}{l}\text { No. of } \\
\text { antibiotics }\end{array}$ & $\begin{array}{l}\text { Multidrug } \\
\text { resistance pattern }\end{array}$ & $\begin{array}{l}\text { No of } \\
\text { isolates }\end{array}$ & $\begin{array}{l}\text { Resistant } \\
\text { rate(\%) }\end{array}$ \\
\hline \multirow[t]{14}{*}{2} & $\mathrm{Mac}+\mathrm{Lin}$ & 1 & $27.56 \%$ & 4 & Lac + Cep + Lin + Qui & 1 & \\
\hline & $\mathrm{Lac}+\mathrm{Sul}$ & 1 & & & $\mathrm{Lac}+\mathrm{Cep}+\mathrm{Lin}+\mathrm{Sul}$ & 2 & \\
\hline & Qui + Sul & 1 & & & $\mathrm{Lac}+\mathrm{Cep}+\mathrm{Lin}+\mathrm{Tet}$ & 3 & \\
\hline & Tet + Sul & 1 & & & $\mathrm{Lac}+\mathrm{Cep}+\mathrm{Mac}+\mathrm{Lin}$ & 2 & \\
\hline & $\mathrm{Nit}+\mathrm{Sul}$ & 2 & & & $\mathrm{Lac}+\mathrm{Cep}+\mathrm{Mac}+\mathrm{Qui}$ & 1 & \\
\hline & Lin + Nit & 3 & & & $\mathrm{Lac}+\mathrm{Cep}+\mathrm{Mac}+$ Tet & 1 & \\
\hline & Lin + Tet & 3 & & & $\mathrm{Lac}+\mathrm{Cep}+\mathrm{Nit}+\mathrm{Tet}$ & 1 & \\
\hline & $\mathrm{Lac}+\mathrm{Aph}$ & 3 & & & Lac + Cep + Qui + Sul & 3 & \\
\hline & Lac+Qui & 3 & & & Lac + Cep + Qui + Tet & 1 & \\
\hline & Lac + Tet & 3 & & & $\mathrm{Lac}+\mathrm{Lin}+\mathrm{Aph}+\mathrm{Nit}$ & 1 & \\
\hline & $\mathrm{Lac}+\mathrm{Cep}$ & 5 & & & $\mathrm{Lac}+\mathrm{Lin}+\mathrm{Nit}+\mathrm{Tet}$ & 3 & \\
\hline & $\mathrm{Lac}+\mathrm{Nit}$ & 6 & & & Lac + Lin + Qui + Sul & 1 & \\
\hline & $\mathrm{Lac}+\mathrm{Mac}$ & 8 & & & Lac + Lin + Qui + Tet & 1 & \\
\hline & Lac + Lin & 22 & & & $\mathrm{Lac}+\mathrm{Mac}+\mathrm{Lin}+\mathrm{Aph}$ & 3 & \\
\hline \multirow[t]{15}{*}{3} & Cep + Qui + Aph & 1 & $19.11 \%$ & & $\mathrm{Lac}+\mathrm{Mac}+\mathrm{Lin}+\mathrm{Qui}$ & 3 & \\
\hline & Lin + Nit + Tet & 1 & & & $\mathrm{Lac}+\mathrm{Mac}+\mathrm{Lin}+\mathrm{Sul}$ & 1 & \\
\hline & $\mathrm{Mac}+\mathrm{Lin}+\mathrm{Sul}$ & 1 & & & Lac + Mac + Lin + Tet & 3 & \\
\hline & $\mathrm{Lac}+\mathrm{Aph}+\mathrm{Nit}$ & 1 & & 5 & $\mathrm{Lac}+\mathrm{Aph}+\mathrm{Nit}+\mathrm{Tet}+\mathrm{Sul}$ & 1 & $4.89 \%$ \\
\hline & $\mathrm{Lac}+\mathrm{Cep}+\mathrm{Lin}$ & 4 & & & $\mathrm{Lac}+\mathrm{Cep}+\mathrm{Lin}+\mathrm{Nit}+\mathrm{Tet}$ & 1 & \\
\hline & Lac + Cep + Qui & 1 & & & $\mathrm{Lac}+\mathrm{Cep}+\mathrm{Mac}+\mathrm{Lin}+\mathrm{Aph}$ & 1 & \\
\hline & $\mathrm{Lac}+\mathrm{Lin}+\mathrm{Aph}$ & 1 & & & $\mathrm{Lac}+\mathrm{Cep}+\mathrm{Mac}+\mathrm{Lin}+\mathrm{Qui}$ & 1 & \\
\hline & $\mathrm{Lac}+\mathrm{Lin}+\mathrm{Nit}$ & 4 & & & $\mathrm{Lac}+\mathrm{Cep}+\mathrm{Mac}+\mathrm{Lin}+\mathrm{Sul}$ & 1 & \\
\hline & $\mathrm{Lac}+\mathrm{Lin}+\mathrm{Sul}$ & 3 & & & $\mathrm{Lac}+\mathrm{Cep}+\mathrm{Mac}+\mathrm{Lin}+\mathrm{Tet}$ & 1 & \\
\hline & Lac + Lin + Tet & 7 & & & $\mathrm{Lac}+\mathrm{Cep}+\mathrm{Qui}+\mathrm{Nit}+\mathrm{Sul}$ & 1 & \\
\hline & $\mathrm{Lac}+\mathrm{Mac}+\mathrm{Aph}$ & 1 & & & $\mathrm{Lac}+\mathrm{Mac}+\mathrm{Lin}+\mathrm{Aph}+\mathrm{Sul}$ & 2 & \\
\hline & $\mathrm{Lac}+\mathrm{Mac}+\mathrm{Lin}$ & 9 & & & $\mathrm{Lac}+\mathrm{Mac}+\mathrm{Lin}+\mathrm{Aph}+\mathrm{Tet}$ & 1 & \\
\hline & $\mathrm{Lac}+\mathrm{Mac}+\mathrm{Nit}$ & 1 & & & $\mathrm{Lac}+\mathrm{Mac}+\mathrm{Lin}+\mathrm{Qui}+\mathrm{Aph}$ & 1 & \\
\hline & $\mathrm{Lac}+\mathrm{Mac}+\mathrm{Sul}$ & 1 & & 6 & $\begin{array}{l}\text { Lac + Cep + Mac + Lin + Nit + } \\
\text { Tet }\end{array}$ & 1 & $2.67 \%$ \\
\hline & $\mathrm{Lac}+\mathrm{Mac}+\mathrm{Tet}$ & 3 & & & $\begin{array}{l}\text { Lac + Cep + Mac + Lin + Qui + } \\
\text { Sul }\end{array}$ & 1 & \\
\hline
\end{tabular}

a Abbreviation: Lac, $\beta$-lactamase; Cep, cephalosporin; Mac, macrolide; Lin, lincomycin; Qui, quinolone; Aph, amphenicol; Nit, nitrofurantoin; Tet, tetracycline; Sul, sulfonamide. 


\begin{tabular}{|c|c|c|c|c|c|c|c|}
\hline $\begin{array}{l}\text { No. of } \\
\text { antibiotics }\end{array}$ & $\begin{array}{l}\text { Multidrug } \\
\text { resistance } \\
\text { pattern }\end{array}$ & $\begin{array}{l}\text { No of } \\
\text { isolates }\end{array}$ & $\begin{array}{l}\text { Resistant } \\
\text { rate(\%) }\end{array}$ & $\begin{array}{l}\text { No. of } \\
\text { antibiotics }\end{array}$ & $\begin{array}{l}\text { Multidrug } \\
\text { resistance pattern }{ }^{a}\end{array}$ & $\begin{array}{l}\text { No of } \\
\text { isolates }\end{array}$ & $\begin{array}{l}\text { Resistant } \\
\text { rate(\%) }\end{array}$ \\
\hline & $\mathrm{Lac}+\mathrm{Qui}+\mathrm{Aph}$ & 1 & & & $\begin{array}{l}\text { Lac + Cep + Mac + Lin + Tet + } \\
\text { Sul }\end{array}$ & 2 & \\
\hline & $\mathrm{Lac}+\mathrm{Qui}+\mathrm{Sul}$ & 1 & & & $\begin{array}{l}\mathrm{Lac}+\mathrm{Lin}+\mathrm{Aph}+\mathrm{Nit}+\mathrm{Tet}+ \\
\text { Sul }\end{array}$ & 1 & \\
\hline & Lac + Qui + Tet & 2 & & & $\begin{array}{l}\mathrm{Lac}+\mathrm{Mac}+\mathrm{Lin}+\mathrm{Qui}+\mathrm{Nit}+ \\
\text { Sul }\end{array}$ & 1 & \\
\hline \multirow[t]{5}{*}{4} & $\begin{array}{l}\text { Aph + Nit + Tet + } \\
\text { Sul }\end{array}$ & 1 & $16.00 \%$ & 7 & $\begin{array}{l}\mathrm{Lac}+\text { Cep + Mac + Lin + Qui + } \\
\text { Aph + Sul }\end{array}$ & 1 & $1.33 \%$ \\
\hline & $\begin{array}{l}\text { Cep + Mac + Lin } \\
+ \text { Tet }\end{array}$ & 1 & & & $\begin{array}{l}\mathrm{Lac}+\mathrm{Mac}+\mathrm{Lin}+\mathrm{Aph}+\mathrm{Nit}+ \\
\text { Tet }+\mathrm{Sul}\end{array}$ & 1 & \\
\hline & $\begin{array}{l}\text { Lac + Aph + Nit + } \\
\text { Tet }\end{array}$ & 1 & & & $\begin{array}{l}\mathrm{Lac}+\mathrm{Mac}+\mathrm{Lin}+\mathrm{Qui}+\mathrm{Aph}+ \\
\mathrm{Nit}+\mathrm{Sul}\end{array}$ & 1 & \\
\hline & $\begin{array}{l}\text { Lac + Cep + Aph } \\
+ \text { Tet }\end{array}$ & 1 & & 8 & $\begin{array}{l}\mathrm{Lac}+\mathrm{Cep}+\mathrm{Mac}+\mathrm{Lin}+\mathrm{Qui}+ \\
\text { Aph + Nit + Sul }\end{array}$ & 1 & \\
\hline & $\begin{array}{l}\text { Lac + Cep + Lin + } \\
\text { Nit }\end{array}$ & 1 & & 9 & $\begin{array}{l}\mathrm{Lac}+\mathrm{Cep}+\mathrm{Mac}+\mathrm{Lin}+\mathrm{Qui}+ \\
\text { Aph + Nit + Tet + Sul }\end{array}$ & 4 & $1.78 \%$ \\
\hline
\end{tabular}

\subsection{Association of antimicrobial resistance phenotype with resistance- associated genes}

PCR was used to detect the major resistance genes for tetracyclines (tetK, tetM, tetL, tetO), macrolides (ermC), and $\beta$-lactamase (blaZ). Amond the 83 strains, tetracycline-resistant CNS group, $66.27 \%$ of them carried tet-type genes, and the rest appeared resistant to tetracycline without detecting out any of the tet-type genes (Table 4). Conversely, there were also 8 isolates carrying the tetK gene in the group of 92 CNS strains that were susceptible to tetracycline. Besides, only two SA isolates carrying tetK and they both were resistant to tetracycline; other tet-type genes were not found in SA in this research. Figure $1 \mathrm{a}, 1 \mathrm{~b}$ and $1 \mathrm{c}$ show the PCR products of the tet-type genes from staphylococci. 
Table 4

Comparison of the genotypic and phenotypic resistance of CNS and SA to antibiotics

\begin{tabular}{|c|c|c|c|c|c|c|c|c|}
\hline Resistant & CNS & & & & Staphylococcu & aureus & & \\
\hline gene & Susceptibility & Resistance & $\begin{array}{l}\text { Occupation } \\
\text { rate }\end{array}$ & $\begin{array}{l}\text { Effective } \\
\text { rate }\end{array}$ & Susceptibility & Resistance & $\begin{array}{l}\text { Occupation } \\
\text { rate }\end{array}$ & $\begin{array}{l}\text { Effective } \\
\text { rate }\end{array}$ \\
\hline $\operatorname{tetk}(+)$ & 6 & 50 & $60.24 \%$ & $89.29 \%$ & 0 & 2 & $25.00 \%$ & $100.00 \%$ \\
\hline tetk(-) & 86 & 33 & & & 112 & 6 & & \\
\hline $\operatorname{tetm}(+)$ & 0 & 5 & $6.02 \%$ & $100.00 \%$ & 0 & 0 & $0.00 \%$ & $100.00 \%$ \\
\hline $\operatorname{tetm}(-)$ & 92 & 78 & & & 112 & 8 & & \\
\hline $\operatorname{tet} /(+)$ & 2 & 2 & $2.41 \%$ & $50 \%$ & 0 & 0 & $0.00 \%$ & $100.00 \%$ \\
\hline $\operatorname{tet} /(-)$ & 90 & 81 & & & 112 & 8 & & \\
\hline blaZ(+) & 7 & 59 & $33.71 \%$ & $89.39 \%$ & 0 & 42 & $26.58 \%$ & $100.00 \%$ \\
\hline blaZ(-) & 43 & 116 & & & 10 & 116 & & \\
\hline ermc(+) & 0 & 7 & $12.73 \%$ & $100.00 \%$ & 0 & 2 & $28.57 \%$ & $100.00 \%$ \\
\hline ermc(-) & 109 & 48 & & & 114 & 5 & & \\
\hline
\end{tabular}

The blaZ ( $\beta$-lactamase) gene was detected in 59 out of 175 CNS strains that were resistant to penicillin, and 7 out of 50 CNS isolates that were susceptive, but 42 SA isolates with blaZ gene all could resist penicillin. Figure $1 \mathrm{~d}$ shows the PCR products of the blaZ gene from staphylococci. The ermC was found in seven CNS strains and two SA strains, and all of them were resistant to erythromycin. Figure $1 \mathrm{e}$ shows the PCR products from the ermC gene from staphylococci. All the above information about the differences between SA and CNS strains was summarized in Table 4. Notably, we found that all SA strains carrying resistance genes were resistant to the related antibiotics, but CNS were not.

\section{Discussion}

Staphylococci are the bacteria most commonly isolated from bovine mastitis [13]. The discussions and comparisons between CNS and SA have often been reported $[6,14]$. Although SA causes more server mastitis than CNS, CNS are now predominant over SA in most countries [6]. Staphylococcus aureus mastitis easily remains persistent [15], but CNS are more able to persist in the mammary gland with causing a moderate increase of milk SCC [16]. In this study, 168 isolates of SA were recovered from subclinical cases in the 6 farms. For 225 CNS isolates, Staphylococcus sciuri (22.67\%) and Staphylococcus xylosus (17.33\%) are identified most frequently. Staphylococcus sciuri is also reported as the commonest CNS species isolated from cows in Poland $[17,18]$; Staphylococcus chromogenes, however, is typically the most commonly identified species in Columbus (USA) or Helsinki (Finland) $[14,19]$.

On the other hand, vitro drug sensitivity tests were conducted on staphylococcal isolates. We found that the most effective antibiotics against CNS and SA were different. Most SA strains were susceptible to clarithromycin (92.26\%), followed by nitrofurantoin (88.69\%) and chloramphenicol (85.71\%). The majority of CNS were sensitive to chloramphenicol (86.67\%), cotrimoxazole (83.56\%) and nitrofurantoin (82.22\%). Therefore, chloramphenicol can defend against most staphylococci; this might due to that the use of chloramphenicol has been banned in food animals in China because of its inhibition of bone marrow hematopoietic function [20]. Fortunately, chloramphenicol now can be replaced by florfenicol, which is also a member of the amide alcohols. Florfenicol was developed in the late 1980s as a new kind of broad-spectrum antibiotic for veterinary use.

The concepts of MDR, XDR and PDR are very important, characterizing the different patterns of resistance found in bacteria. But there were many different definitions for them until 2012, Magiorakos reported and defined them [21]. According to the report, we exercised statistic data; from Table 2 and Table 3, it can be seen that most of SA were quadruple-drug resistances, and most CNS resist double. However, CNS seem to outperform SA in resisting six or more classes of drugs; there were even 4 strains of CNS are PDR strains that were non-susceptible to all of the 15 kinds of antibiotics used in this study. This point agrees with the view that 
CNS tend to be more resistant to antimicrobials than SA and easily develop multiresistance [11]. Therefore, CNS are more likely represented as a reservoir which transmitted antibiotic-resistance to other staphylococci like SA [11].

According to the chi-square test results, we summary and find that quinolones (ciprofloxacin, levofloxacin, and norfloxacin) and co-trimoxazole antibiotics, both interfere with the metabolism of nucleotides. They affected CNS significantly more than SA. Quinolones antibiotics can trap the bacterial topoisomerases on DNA [22] and co-trimoxazole includes trimethoprim work as a tetrahydrofolate reductase inhibitor, and sulfamethoxazole provides a second blockage of the folate biosynthetic pathway [23]. Therefore, whatever the results in Jiangsu, Finland [13], or Portuguese [24], there might be mechanisms or compounds that tend to protect nucleotide metabolism in SA from these antibiotics under pressure from these kinds of antibiotics. Proctor proposes that the special thermonuclease in SA could release extra thymidine from bacterial inoculum and mammalian tissues, so they can bypass the metabolic blockades caused by co-trimoxazole [25]. We remained unknown whether this release process could also affect the working mechanism of quinolones or there are other defense mechanisms in SA.

Equally, We also compare the resistance of CNS and SA to lincomycins (clindamycin), macrolides (including erythromycin and clarithromycin), tetracycline, and nitrofurantoin antibiotics; those antibiotics all interfere the bacterial protein synthesis by inhibiting the prolonging of peptide chains [26-28]. We summary and found that the antimicrobial resistance rates of CNS to them were significantly higher than that of SA; that is to say, they affected CNS significantly less than SA in general. Moreover, it can be found that resistance genes were detected much more frequently in CNS than SA, which means resistance genes may have more contribution in CNS than SA. Taponen also reported that CNS were more resistant to macrolides, lincosamides, oxytetracycline and fusidic acid in Finland [29]. These are partly in line with the view CNS tend to be more resistant to antimicrobials than SA $[6,11]$.

Macrolides (MLS) and lincomycin antibiotics have similar binding sites in the 50 S ribosomal subunit. It can irreversibly bind to bacterial ribosomal 23SrRNA and selectively inhibit protein synthesis by blocking tranlspeptide action and mRNA shift [26]. The erm gene can methylate specific nucleotide residues of 23SrRNA, resulting in their resistance to macrolides, lincosamide, and streptomycin B with the same target position, clinically known as MLS resistance. Chi-square test results show that CNS were significantly more resistant to macrolides (erythromycin and clarithromycin) or lincomycin (clindamycin) than SA in this area. At the genetic level, the detection rate of $e r m C$ in the CNS is also higher than that of SA. MLS resistance can be divided into constitutive (cMLS) and induced (iMLS) resistance [30]. The resistance of cMLS type could resist erythromycin and clindamycin, which could be detected routinely in vitro drug sensitivity tests. However, iMLS resistance means that erythromycin, as an inducer, can induce erm gene expression through the attenuating mechanism to produce resistance toward clindamycin; hence some bacteria with iMLS could be resistant to erythromycin and sensitive to clindamycin in vitro drug sensitivity assay, but clindamycin might be ineffective to them in clinical treatment [31]. Therefore, ermC is often added to the drug sensitivity test to prevent clinical drug failure. The detection rate of erm $\mathrm{C}$ in this study was $3.1 \%$ in CNS and $1.2 \%$ in SA; both were low, indicating that the most clinical susceptibility results should be valid and the probability of clinical clindamycin failure is low. It also shows that the resistant models of CNS and SA to macrolides and lincomycin drugs were little dominated by the ermC mechanism in Jiangsu province. The resistance rate of staphylococci to erythromycin in Jiangsu area (15.78\%) is still somewhat high, and CNS were significantly more resistant to macrolides (erythromycin and clarithromycin) or lincomycin (clindamycin) than SA

Besides, tetK, tetM, tetL and tetO, the major resistance genes that defend against tetracycline antibiotics in staphylococci, were detected in this study. We found that staphylococcal resistance to tetracycline is mainly mediated by energy-dependent efflux of tetracycline in this area; the tetK and tet $L$ genes encode proteins that pump out tetracycline, but this cannot remove minocycline [32]. Another resistance mechanism, ribosomal protection proteins (RPPs), plays a minor role in this area. RPPs are encoded by tetO and tetM; together of them were only detected out a tiny proportion, $1.2 \%$, in all isolated staphylococci. RPPs result in an allosteric disruption of primary tetracycline binding and consequently release of the drug. This mechanism confers resistance to tetracyclines and minocycline [33]. Therefore, although $26.6 \%$ of CNS can resist tetracycline theoretically due to the energydependent efflux of tetracycline, most of them should be susceptible to minocycline. Phenotypic antimicrobial-resistant observations of this study were also supported this hypothetical pattern.

A related point to consider is that, for minocycline and chloramphenicol, they are not used in these 6 farms and chloramphenicol is forbidden to be used in China. Few CNS and SA isolates were resistant to these two in this study, and the chi-square test results 
of them didn't show a significant difference between SA and CNS. Therefore, we speculate that only after its involvement, the stress of antibiotics interfering with protein synthesis, CNS strains might be more likely to become the mutations to survive than SA. Interestingly, recently Fernando also makes a very similar interpretation on another kind of bacteria; he assumed that the evolutionary landscapes of Pseudomonas aeruginosa towards ribosome-targeting antibiotic resistance depend on selection strength [34]. We further proposed that this evolutionary also relies on the classes of antibiotics and the species of bacteria.

\section{Conclusion}

This study revealed the characters of antibiotic-resistant patterns of CNS and SA in Jiangsu Province of China. Staphylococcus aureus might be more likely to survive from antibiotics that interfere the metabolism of nucleotides, and CNS strains might be more likely to become the mutations to survive than SA, responding to the stress from antimicrobial interfering in bacterial protein synthesis. The evolutionary landscapes of staphylococci towards antibiotic resistance are affected by the classes of antibiotics and the species of bacteria.

\section{Methods}

\subsection{Sampling}

Milk samples, which were positive by the California Mastitis Test (CMT), were collected from six dairy farms in Jiangsu Province, China, from March 2015 to March 2016. The experimental scheme of this study is outlined in Fig. 2. Before sampling $10 \mathrm{~mL}$ milk aseptically as described [35], the teat ends were disinfected with moist cotton swabs (10 to $15 \mathrm{~s}$ ) soaked in $70 \%$ alcohol then dried with a paper towel, and the first streams of milk were discarded. The milk tubes were transported on ice to the Key Laboratory of Jiangsu Preventive Veterinary Medicine.

To obtain a representative sample of the herds on Jiangsu Province, we selected the farms for this study according to the following criteria: (i) the farm had a minimum of 100 lactating cows, (ii) the average milk production was above $5500 \mathrm{~kg}$ of milk per cow per year, (iii) the cows were milked twice daily at 7:00 a.m. and 4:00 p.m., (iv) the cows all were Holstein. Milk samples from dairy cows with mastitis were obtained from six herds in total from four districts (2 herds in Yangzhou, 2 herds in Suzhou, and 2 herds in Changzhou and Nantong); the mean herd size of them was 196; the antibiotic list they used in farms are penicillin, ceftriaxone, levofloxacin, kanamycin, amikacin, tetracycline, norfloxacin, ceftazidime, and streptomycin. Due to that the tetracycline, macrolide, and $\beta$-lactamase are most used in these farms, we choose the corresponding and common resistance genes (tetK, tetM, tetL, tetO, ermC, and blaZ) to explore their general resistance mechanisms.

For this study, all of the staphylococci were isolated from milk samples from dairy cows with subclinical mastitis. All the udder quarter milk from subclinical mastitic cows was analyzed by the CMT by veterinarians. The CMT-reaction is graded 1 to 5 . The scores are ranked according to an increase in viscosity, where the highest viscosity (CMT 5) is roughly correlated to the highest SCC. If the udder quarter milk had a CMT score $\geq 3$, it would be determined as test positive.

\subsection{Laboratory Bacteriological Culture}

Milk samples were examined by procedures as Laboratory Handbook on Bovine Mastitis recommended by the American National Mastitis Council [36]. Briefly, milk samples $(100 \mu \mathrm{L})$ from mammary quarters were plated onto trypticase soy agar (TSA) plates supplemented with $5 \%$ (vol/vol) defibrinated sheep blood (Hangzhou Tianhe Microorganism Reagent Ltd., Hangzhou, China). Inoculated plates were incubated at $37^{\circ} \mathrm{C}$. After incubation for 18 to $24 \mathrm{~h}$, all plates were observed for microbial growth. If bacteria did not grow, the plate was returned to the incubator for an additional 18-24 $\mathrm{h}$ and then reevaluated for microbial growth. Those plates showing growth were recorded, and species identification started. If a quarter milk sample resulted in the culture of 3 or more dissimilar colony types, the milk sample would be recorded as contaminated and excluded from the study. Isolates were Gram-stained to assist in organism identification.

Staphylococci were identified by means of typical colony morphology, gram-positive coccal staining and by being tube catalasepositive; if the above staphylococci were with hemolysis, pigmented colonies and tube coagulase-positive then they were classified as SA potential, or they were classified as CNS potential. What calls for special attention is that, although both

Page 10/18 
Staphylococcus intermedius and Staphylococcus hyicus colonies are both tube coagulase-positive like SA, they are nonpigmented; Staphylococcus hyicus do not produce hemolysis. Therefore, they should be distinguishable in the experiment. The obtained 393 staphylococci were selected for further identified by Vitek 2 system with Gram-positive identification card (GPI; bioMerieux Vitek) and detecting drug sensitivity and resistant genes. For the non-definitive strains, 16S rRNA genes were amplified for sequencing by BGI (China), and the primers were shown in Table 5 [37].

Table 5

PCR primers and conditions for amplification of drug resistance genes

\begin{tabular}{|c|c|c|c|c|}
\hline Gene & Oligonucleotide sequence (5囚-3囚) & Annealing Temp $\left({ }^{\circ} \mathrm{C}\right)$ & Fragment size (bp) & Reference \\
\hline \multirow[t]{2}{*}{$16 S$ rRNA } & AGAGTTTGATCMTGGCTCAG & \multirow[t]{2}{*}{51} & \multirow[t]{2}{*}{927} & \multirow[t]{2}{*}{ [37] } \\
\hline & CCGTCAATTCMTTTRAGTTT & & & \\
\hline \multirow[t]{2}{*}{ tetK } & TCGATAGGAACAGCAGTA & \multirow[t]{2}{*}{55} & \multirow[t]{2}{*}{169} & \multirow[t]{2}{*}[40]{} \\
\hline & CAGCAGATCCTACTCCTT & & & \\
\hline \multirow[t]{2}{*}{ tetM } & CCGCACССTCTACTACAA & \multirow[t]{2}{*}{56} & \multirow[t]{2}{*}{351} & X56353 \\
\hline & САТTССАСТTСССАACG & & & $1246-1597$ bp \\
\hline \multirow[t]{2}{*}{ tetO } & GCGGAACATTGCATTTGAGGG & \multirow[t]{2}{*}{60} & \multirow[t]{2}{*}{538} & \multirow[t]{2}{*}{ [39] } \\
\hline & CTCTATGGACAACCCGACAGAAG & & & \\
\hline \multirow[t]{2}{*}{ tetL } & GGATCGATAGTAGCCATGGG & \multirow[t]{2}{*}{59} & \multirow[t]{2}{*}{516} & \multirow[t]{2}{*}{ [39] } \\
\hline & GTATCCCACCAATGTAGCCG & & & \\
\hline \multirow[t]{2}{*}{ blaZ } & AAGAGATTTGCCTATGCTTC & \multirow[t]{2}{*}{55} & \multirow[t]{2}{*}{517} & \multirow[t]{2}{*}{ [41] } \\
\hline & GCTTGACCACTTTTATCAGC & & & \\
\hline \multirow[t]{2}{*}{ ermC } & CTTGTTGATCACGATAATTTCC & \multirow[t]{2}{*}{55} & \multirow[t]{2}{*}{190} & \multirow[t]{2}{*}{ [42] } \\
\hline & ATCTTTTAGCAAACCCGTATTC & & & \\
\hline
\end{tabular}

On the other hand, colonies suspected as being streptococci by colony morphology, Gram-positive cocci, as well as catalasenegative; bacillus were determined by Gram-staining bacillus under the oil mirror. Both of them were not further characterized in this paper.

\subsection{Drug Susceptibility Testing}

The disk diffusion method was used for antibiotic susceptibility tests and the results were read based on the recommendations of the Clinical and Laboratory Standards Institute (CLSI, 2010a) of the USA. The antibiotics penicillin ( $\beta$-lactamase), co-trimoxazole (sulfonamide), cefotaxime (cephalosporin), clarithromycin (macrolide), ceftriaxone (cephalosporin), chloramphenicol (amphenicol), ceftazidime (cephalosporin), ciprofloxacin (quinolone), nitrofurantoin, tetracycline (tetracycline), erythromycin (macrolide), levofloxacin (fluoroquinolone), minocycline (tetracycline), norfloxacin (fluoroquinolone), and clindamycin (lincomycin) were used in this study; they were universal therapeutic agents against Gram-positive bacteria and purchased from Hangzhou Tianhe Microorganism Reagent Co., Ltd. Antimicrobial agent concentrations on each absorbent paper and the interpretative criteria are shown in Table 6, and the tests were performed on Mueller-Hinton agar (Hangzhou Tianhe Microorganism Reagent Ltd.) with incubation at $37^{\circ} \mathrm{C}$ for $24 \mathrm{~h}$. SA ATCC 25923 was used as a quality control strain tested in parallel with each batch of isolates, and on all occasions, the results were within acceptable ranges according to the specifications of the CLSI. Each diffusion was examined carefully by using incident light to examine the plate.

Table 6. Antimicrobial sensibility test paper specifications and determinant criteria 


\begin{tabular}{|c|c|c|c|c|c|}
\hline \multirow[t]{2}{*}{ Antibiotic } & \multirow{2}{*}{$\begin{array}{l}\text { Concentration } \\
(\mu \mathrm{g} / \mathrm{disk})\end{array}$} & $\begin{array}{l}\text { Breakpoint value } \\
(\mathrm{mm})^{1}\end{array}$ & \multirow[t]{2}{*}{ Antibiotic } & \multirow{2}{*}{$\begin{array}{l}\text { Concentration } \\
\text { ( } \mu \mathrm{g} / \mathrm{disk})\end{array}$} & $\begin{array}{l}\text { Breakpoint value } \\
(\mathrm{mm})^{1}\end{array}$ \\
\hline & & $R \mid S$ & & & $R \mid S$ \\
\hline Penicillin & $10 I U$ & $\leqq 28,-, \geqq 29$ & $\begin{array}{l}\text { Co- } \\
\text { trimoxazole }\end{array}$ & $1.25 / 23.75$ & $\leqq 10,11-15, \geqq 16$ \\
\hline Cefotaxime & 30 & $\leqq 14,15-22, \geqq 23$ & Clarithromycin & 15 & $\leqq 13,14-17, \geqq 18$ \\
\hline Ceftriaxone & 30 & $\leqq 13,14-20, \geqq 21$ & Norfloxacin & 10 & $\leqq 12,13-16, \geqq 17$ \\
\hline Levofloxacin & 5 & $\leqq 15,16-18, \geqq 19$ & Ceftazidime & 30 & $\leqq 14,15-17, \geqq 18$ \\
\hline Chloramphenicol & 30 & $\leqq 12,13-17, \geqq 18$ & Nitrofurantoin & 300 & $\leqq 14,15-16, \geqq 17$ \\
\hline Ciprofloxacin & 5 & $\leqq 15,16-20, \geqq 21$ & Minocycline & 30 & $\leqq 14,15-18, \geqq 19$ \\
\hline Tetracycline & 30 & $\leqq 14,15-18, \geqq 19$ & Clindamycin & 2 & $\leqq 14,15-20, \geqq 21$ \\
\hline Erythromycin & 15 & $\leqq 13,14-22, \geqq 23$ & & & \\
\hline
\end{tabular}

${ }^{1}$ Breakpoint value $(\mathrm{mm})$ : R, resistant; I, intermediate; S, susceptible.

\subsection{DNA Extraction and PCR Conditions}

Bacterial DNA was prepared as previously described [38] and used in PCR. Table 5 shows base sequences and predicted sizes of amplified products for the specific oligonucleotide primers used in this study. The oligonucleotide primer for the tetM gene was designed according to the nucleotide sequence of the tetM gene (GenBank: X56353.1), and other sequences have been described elsewhere $[39,40]$. The PCR reactions were performed in a total volume of $20 \mu \mathrm{L}$, including $1 \mu \mathrm{L}$ of template DNA, $0.5 \mu \mathrm{M}$ primers (Invitrogen, China), and $10 \mu \mathrm{L} 2 \times$ PCR Master Mix (Thermo, China). Amplification reactions were carried out using a DNA thermal cycler (GeneAmp PCR system 9700, Applied Biosystems, USA) as follows: thermal denaturation at $94{ }^{\circ} \mathrm{C}$ for 5 min followed by 32 cycles of denaturation at $95^{\circ} \mathrm{C}$ for $1 \mathrm{~min}$, primer annealing (temperature as in Table 5) for $1 \mathrm{~min}$, and DNA extension at $72{ }^{\circ} \mathrm{C}$ for $45 \mathrm{~s}$. After the last cycle, the samples were kept at $72{ }^{\circ} \mathrm{C}$ for $10 \mathrm{~min}$ to complete the synthesis of all strands. The amplified products were visualized by standard submarine gel electrophoresis with $10 \mu \mathrm{L}$ of the final reaction mixture on a $1 \%$ agarose gel in TBE buffer ( $89 \mathrm{mM}$ Tris, $89 \mathrm{mM}$ boric acid, $2.5 \mathrm{mM}$ EDTA, PH 8.3). The samples were electrophoresed for $45 \mathrm{~min}$ at $80 \mathrm{~V}$. Amplified DNA fragments of specific sizes were located by U.V. fluorescence after being stained with ethidium bromide. Molecular size markers (DL 2000) (Takara, China) were included in each gel.

\subsection{Statistical Analysis}

Chi-square tests were performed using SPSS Software version 20 (IBM SPSS Statistics for Windows, Armonk, NY, USA) to compare the number of antibiotic-resistant strains and the total number of susceptible strains and intermediate strains between CNS and SA within the same antibiotic. In the test, $P<0.05$ was considered statistically significant. Moreover, the occupation rate, also called sensitivity according to Martin's described [43], was used to estimate the contribution rate of each resistant gene in bacteria with resistance to corresponding drugs; the true positive rate of each resistant gene, also called effective rate, was used to evaluate the proportion of each resistant gene in bacteria with the real effective to resist relative drugs. Both were used to investigate the connections between phenotypic and genotypic resistance. The true positive sample number means the number of strains containing resistance genes and also resisting related antibiotics. The formulae for calculating them are shown below:

$$
\begin{aligned}
\text { Occupation } \% & =\frac{\text { True positive number of bacteria containing resistance genes }}{\text { The number of strains resist corresponding antibiotics }} \times 100 \% \\
\text { True positive } \%= & \frac{\text { True positive number of bacteria containing resistance genes }}{\text { The number of strains containing corresponding resistant genes }} \times 100 \%
\end{aligned}
$$

\section{Abbreviations}




\begin{tabular}{|c|c|}
\hline Abbreviation & Full Name \\
\hline bp & Base pair \\
\hline CMT & California Mastitis Test \\
\hline CLSI & The Clinical and Laboratory Standards Institute \\
\hline SA & Staphylococcus aureus \\
\hline CNS & Coagulase Negative Staphylococci \\
\hline DNA & Deoxyribonucleoside triphosphate \\
\hline dNTP & Deoxyribonucleoside triphosphate \\
\hline g & Gram \\
\hline $\mathrm{h}$ & Hour \\
\hline $\min$ & Minute \\
\hline $\mathrm{mL}$ & Milliliter \\
\hline $\mathrm{mm}$ & Millimeter \\
\hline PCR & Polymerase chain reaction \\
\hline rpm & Revolutions per minute \\
\hline s & Second \\
\hline SCC & Somatic cell count \\
\hline $\mathrm{Tm}$ & Annealing Ttemperature \\
\hline$\mu \mathrm{L}$ & Microliter \\
\hline${ }^{\circ} \mathrm{C}$ & Centidegree \\
\hline Lac & $\beta$-lactamase \\
\hline Cep & Cephalosporin \\
\hline Mac & Macrolide \\
\hline Lin & Lincomycin \\
\hline Qui & Quinolone \\
\hline Aph & Amphenicol \\
\hline Tet & Tetracycline \\
\hline Sul & Sulfonamide \\
\hline Nit & Nitrofurantoin \\
\hline $\mathrm{R}$ & Resistant \\
\hline I & Intermediate \\
\hline S & Susceptible \\
\hline
\end{tabular}

\section{Declarations}


All the animal experiments were performed according to the institutional animal care guidelines and approved by the Institutional Animal Care and Use Committee of Yangzhou University.

\section{Consent for publication}

Not applicable.

\section{Availability of data and materials}

The datasets used and/or analysed during the current study are available from the corresponding author on reasonable request.

\section{Competing interests}

The authors declare that they have no competing interests.

\section{Funding}

This work was supported by the Yangzhou Social Development of Science and Technology Research Project [YZ2011091], the Agricultural Science and Technology Innovation Fund of Jiangsu Province, China [CX(14)2088], the Qing Lan Project, and the Priority Academic Program Development of Jiangsu Higher Education Institutions (PAPD). The funding group provided the financial support to cover the costs of the material used for research without intellectually contributing, analysis or interpreting.

\section{Authors' contributions}

WDL, WJJ and QF analyzed the data and wrote the manuscript. DSZ, WD and JY collected the samples, and isolated the strains. AJQ edited the manuscript. JWJ acquired funding, supervised, designed the study, reviewed the manuscript. All authors read and approved the final manuscript.

\section{Acknowledgments}

Not applicable.

\section{Author details}

${ }^{a}$ Key Lab for Animal Preventive Medicine, Jiangsu Co-innovation Center for Prevention and Control of Important Animal Infectious Diseases and Zoonoses, Department of Veterinary Medicine, Yangzhou University, Yangzhou 225009, China. ${ }^{b}$ Molecular and Cellular Biology, Gembloux Agro-Bio Tech University of Liège (ULg), Gembloux, Belgium

\section{References}

1. Condas LAZ, De BJ, Nobrega DB, Carson DA, Naushad S, De Vliegher S, et al. Prevalence of non-aureus staphylococci species causing intramammary infections in Canadian dairy herds. J Dairy Sci. 2017;100(7):5592-612.

2. Wald R, Hess C, Urbantke V, Wittek T, Baumgartner M. Characterization of Staphylococcus species isolated from bovine quarter milk samples[J]. Animals. 2019;9(5):200.

3. Anaya-Lopez JL, Contreras-Guzman OE, Carabez-Trejo A, Baizabal-Aguirre VM, Lopez-Meza JE, Valdez-Alarcon JJ, et al. Invasive potential of bacterial isolates associated with subclinical bovine mastitis. Res Vet Sci. 2006;81:358-61.

4. Hennekinne JA, De Buyser ML, Dragacci S. Staphylococcus aureus and its food poisoning toxins: characterization and outbreak investigation. FEMS Microbiol Rev. 2012;36:815-36.

5. Kuang Y, Tani K, Synnott AJ, Ohshima K, Higuchi H, Nagahata H, et al. Characterization of bacterial population of raw milk from bovine mastitis by culture-independent PCR-DGGE method. Biochem Eng J. 2009;45:76-81.

6. Taponen S, Pyörälä S. Coagulase-negative staphylococci as cause of bovine mastitis- not so different from Staphylococcus aureus? Vet Microbiol. 2009;134:29-36. 
7. Schukken YH, González RN, Tikofsky LL, Schulte HF, Santisteban CG, Welcome FL, et al. CNS mastitis: Nothing to worry about? Vet Microbiol. 2009;134:9-14.

8. Lam TJ, Schukken YH, van Vliet JH, Grommers FJ, Tielen MJ, Brand A. Effect of natural infection with minor pathogens on susceptibility to natural infection with major pathogens in the bovine mammary gland. Am J Vet Res. 1997;58:17-22.

9. Soumya KR, Philip S, Sugathan S, Mathew J, Radhakrishnan EK. Virulence factors associated with Coagulase Negative Staphylococci isolated from human infections. 3 Biotech. 2017;7(2):140.

10. Achek R, Cantekin Z, Oumouna M, Mahdi A, Hamdi T. Occurrence of enterotoxins, Exfoliative Toxins and Toxic Shock Syndrome Toxin-1 genes in Staphylococcus aureus and CoNS isolated from clinical and food samples in Algeria. HVM Bioflux. 2018;10:85-92.

11. Suvi T, Satu P. How important is coagulase-negative Staph as a cause of mastitis? NMC 46th annual meeting Proceedings. San Antonio: National Mastitis Council; 2007.

12. Jayadev-Menon P, Humphreys $H$, Fitzgerald-Hughes D. Could coagulase negative staphylococci be an evolutionary source of resistance genes for Staphylococcus aureus? BMC Proc. 2015;9(1):1-1.

13. Condas LAZ, De Buck J, Nobrega DB, Carson DA, Naushad S, De Vliegher S, et al. Prevalence of non-aureus staphylococci species causing intramammary infections in Canadian dairy herds. J Dairy Sci. 2017;100:5592-612.

14. Taponen S, Simojoki H, Haveri M, Larsen HD, Pyorala S. Clinical characteristics and persistence of bovine mastitis caused by different species of coagulase-negative staphylococci identified with API or AFLP. Vet Microbiol. 2006;115:199-207.

15. Larsen HD, Sloth KH, Elsberg C, Enevoldsen C, Pedersen LH, Eriksen NH, et al. The dynamics of Staphylococcus aureus intramammary infection in nine Danish dairy herds. Vet Microbiol. 2000;71:89-101.

16. Myllys V. Staphylococci in heifer mastitis before and after parturition. J Dairy Res. 1995;62:51-60.

17. Bochniarz M, Wawron W, Szczubial M. Coagulase-negative staphylococci (CNS) as an aetiological factor of mastitis in cows. Pol J Vet Sci. 2013;16:487-92.

18. Malinowski E, Lassa H, Kllossowska A, Smulski S, Markiewicz H, Kaczmarowski M. Etiological agents of dairy cows' mastitis in western part of Poland. Pol J Vet Sci. 2006;9:191-4.

19. Rajala-Schultz PJ, Smith KL, Hogan JS, Love BC. Antimicrobial susceptibility of mastitis pathogens from first lactation and older cows. Vet Microbiol. 2004;102:33-42.

20. Ehrlich J, Bartz QR, Smith RM, Joslyn DA, Burkholder PR. Chloromycetin, a New Antibiotic From a Soil Actinomycete. Science. 1947;106:417.

21. Magiorakos AP, Srinivasan A, Carey RB, Carmeli Y, Falagas ME, Giske CG, et al. Multidrug-resistant, extensively drug-resistant and pandrug-resistant bacteria: an international expert proposal for interim standard definitions for acquired resistance. Clin Microbiol Infect. 2012;18:268-81.

22. Drlica K, Malik M, Kerns RJ, Zhao X. Quinolone-mediated bacterial death. Antimicrob Agents Chemother. 2008;52:385-92.

23. Huovinen P. Resistance to trimethoprim-sulfamethoxazole. Clin Infect Dis. 2001;32:1608-14.

24. Melo-Cristino J. Antimicrobial resistance in staphylococci and enterococci in 10 Portuguese hospitals in 1996 and 1997. Microb Drug Resist. 1998;4:319-24.

25. Proctor RA. Role of folate antagonists in the treatment of methicillin-resistant Staphylococcus aureus infection. Clin Infect Dis. 2008;46:584-93.

26. Tu D, Blaha G, Moore PB, Steitz TA. Structures of MLSBK antibiotics bound to mutated large ribosomal subunits provide a structural explanation for resistance. Cell. 2005;121:257-70.

27. Schnappinger D, Hillen W. Tetracyclines: antibiotic action, uptake, and resistance mechanisms. Clin Infect Dis. 1996;165:35969.

28. McOsker CC, Fitzpatrick PM. Nitrofurantoin: mechanism of action and implications for resistance development in common uropathogens. J Antimicrob Chemother. 1994;33:23-30.

29. Pitkälä A, Haveri M, Pyörälä S, Myllys V, Honkanen-Buzalski T. Bovine Mastitis in Finland 2001-Prevalence, Distribution of Bacteria, and Antimicrobial Resistance. J Dairy Sci. 2004;87(8):2433-41. 
30. Novotna G, Adamkova V, Janata J, Melter O, Spizek J. Prevalence of resistance mechanisms against macrolides and lincosamides in methicillin-resistant coagulase-negative staphylococci in the Czech Republic and occurrence of an undefined mechanism of resistance to lincosamides. Antimicrob Agents Chemother. 2005;49:3586-9.

31. Leclercq R. Mechanisms of resistance to macrolides and lincosamides: nature of the resistance elements and their clinical implications. Clin Infect Dis. 2002;34:482-92.

32. Aminov RI, Garrigues-Jeanjean N, Mackie RI. Molecular ecology of tetracycline resistance: Development and validation of primers for detection of tetracycline resistance genes encoding ribosomal protection proteins. Appl Environ Microbiol. 2001;67:22-32.

33. Connell SR, Tracz DM, Nierhaus KH, Taylor DE. Ribosomal protection proteins and their mechanism of tetracycline resistance. Antimicrob Agents Chemother. 2003;47(12):3675-81.

34. Sanz-Garcia F, Sanchez MB, Hernando-Amado S, Martinez JL. Evolutionary landscapes of Pseudomonas aeruginosa towards ribosome-targeting antibiotic resistance depend on selection strength. Int J Antimicrob Agents. 2020;55:105965.

35. Pitkälä A, Haveri M, Pyörälä S, Myllys V, Honkanen-Buzalski T. Bovine mastitis in Finland 2001-prevalence, distribution of bacteria, and antimicrobial resistance. J Dairy Sci. 2004;87:2433-41.

36. Joseph S. Hogan C, Gonzalez RN, Harmon RJ, Nickerson SC, Oliver SP, Pankey JW, et al. Laboratory Handbook on Bovine Mastitis. Verona: National Mastitis Council Inc; 1999.

37. Park JY, Fox LK, Seo KS, McGuire MA, Park YH, Rurangirwa FR, et al. Comparison of phenotypic and genotypic methods for the species identification of coagulase-negative staphylococcal isolates from bovine intramammary infections. Vet Microbiol. 2011;147:142-8.

38. Blanco M, Blanco JE, Mora A, Dahbi G, Alonso MP, Gonzalez EA, et al. Serotypes, virulence genes, and intimin types of Shiga toxin (verotoxin)-producing Escherichia coli isolates from cattle in Spain and identification of a new intimin variant gene (eaexi). J Clin Microbiol. 2004;42:645-51.

39. Pyörälä S, Taponen S. Coagulase-negative staphylococci-emerging mastitis pathogens. Vet Microbiol. 2009;134(1-2):3-8.

40. Garofalo C, Vignaroli C, Zandri G, Aquilanti L, Bordoni D, Osimani A, et al. Direct detection of antibiotic resistance genes in specimens of chicken and pork meat. Int J Food Microbiol. 2007;113:75-83.

41. Sawant AA, Gillespie BE, Oliver SP. Antimicrobial susceptibility of coagulase-negative Staphylococcus species isolated from bovine milk. Vet Microbiol. 2009;134:73-81.

42. Martineau F, Picard FJ, Grenier L, Roy PH, Ouellette M, Bergeron MG, et al. Multiplex PCR assays for the detection of clinically relevant antibiotic resistance genes in staphylococci isolated from patients infected after cardiac surgery. $J$ Antimicrob Chemother. 2000;46:527-33.

43. Martin SW. Estimating disease prevalence and the interpretation of screening. Preventive Veterinary Medicine 1984; 2(1-4): $463-72$.

\section{Figures}


a)

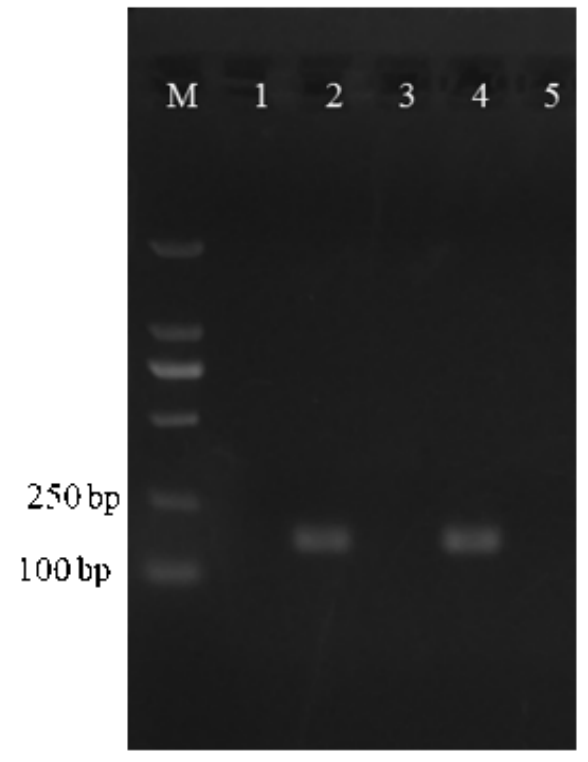

b)

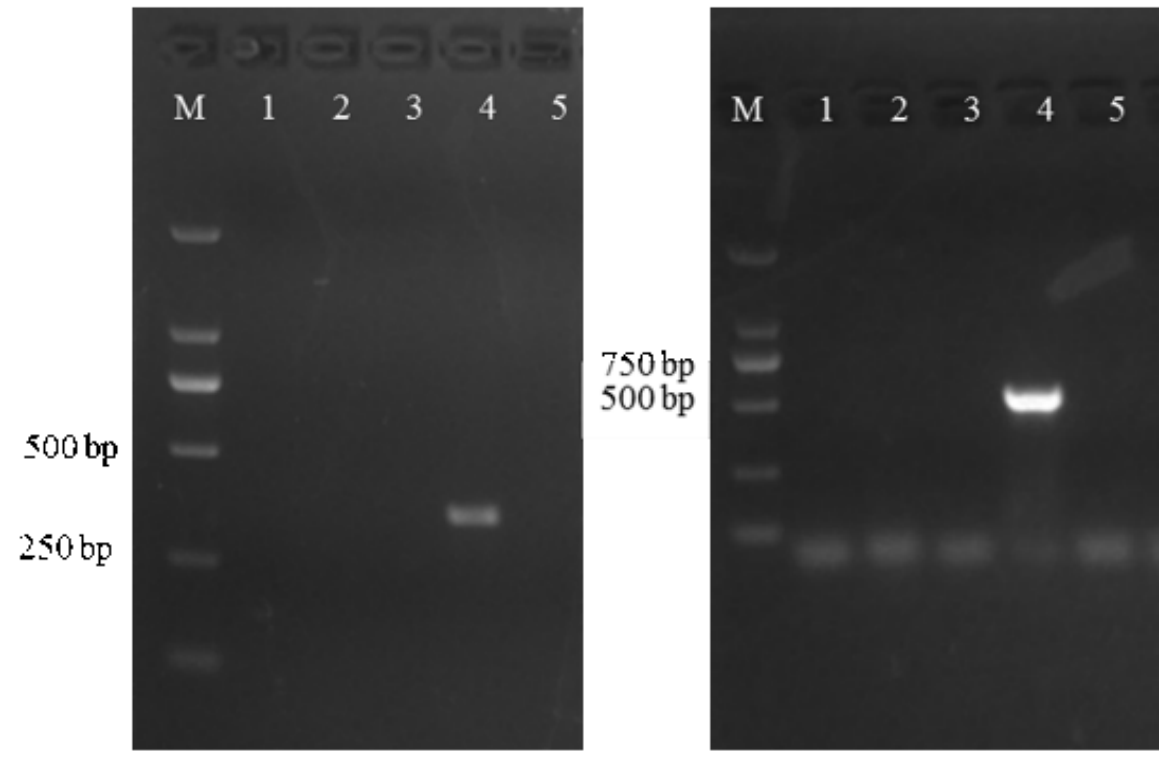

d)
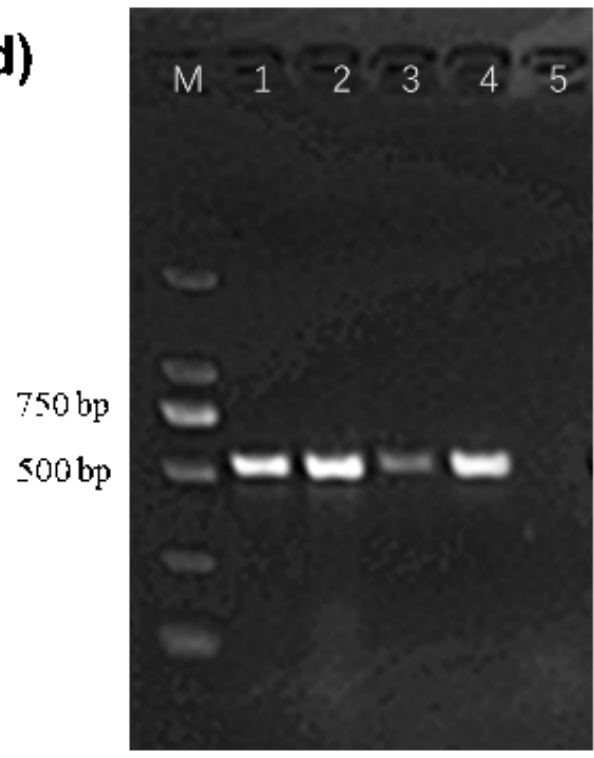

c)

e)

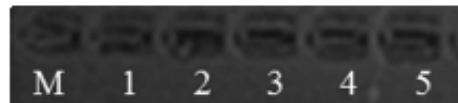

$250 \mathrm{bp}$

100 bp

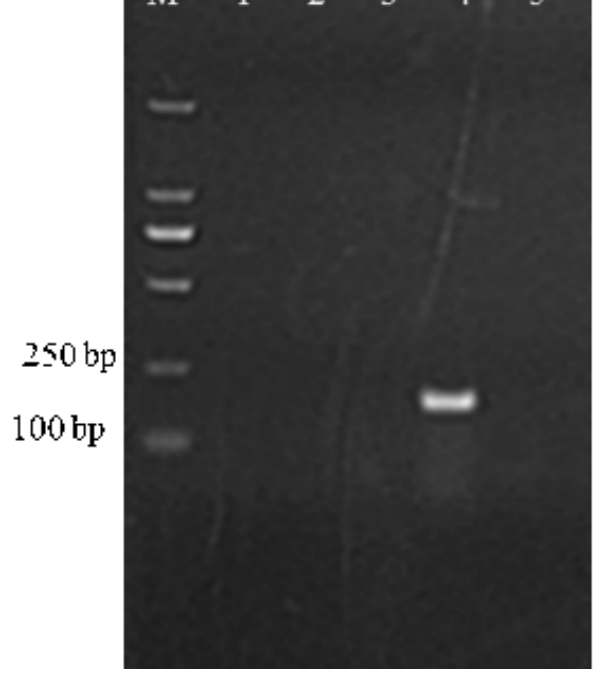

\section{Figure 1}

Detection of resistant genes from staphylococci by PCR. Lane M: DL2000 marker; lane 1 to 3: PCR products from staphylococci; lane 4: positive PCR control; lane 5: negative PCR control without DNA. a) - e): PCR amplification results of the tetK, tetM, tetL, blaZ, and ermC gene, respectively. 


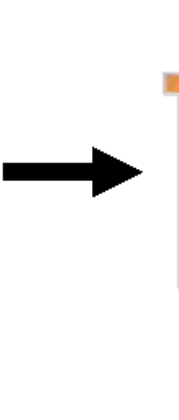

Milk samples

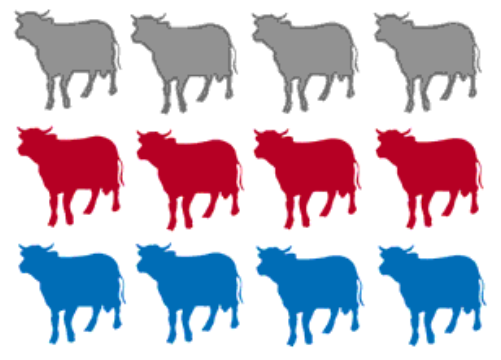

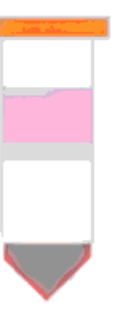

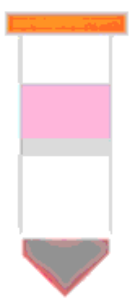

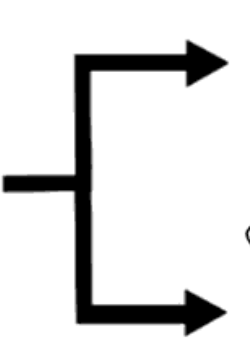

Bacteriological isolate

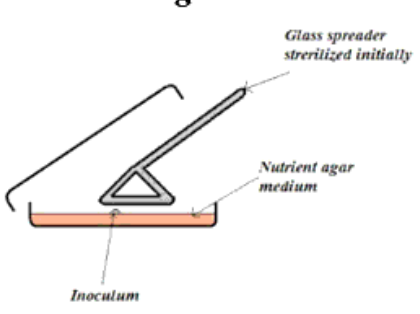

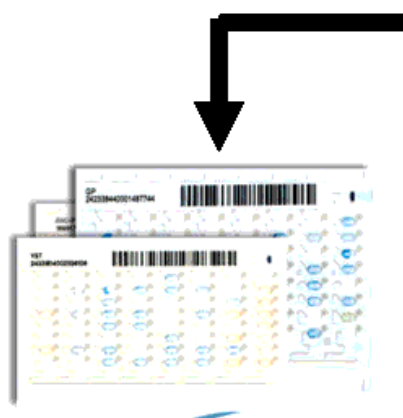

VITEK 2

Identified Staphylococci

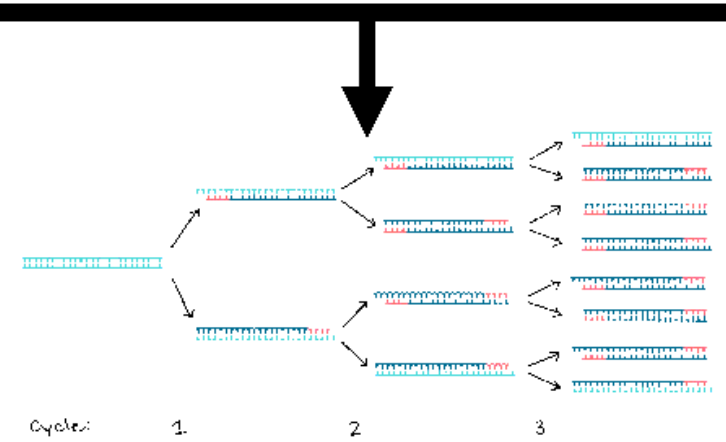

Determined resistance-associated genes by PCR

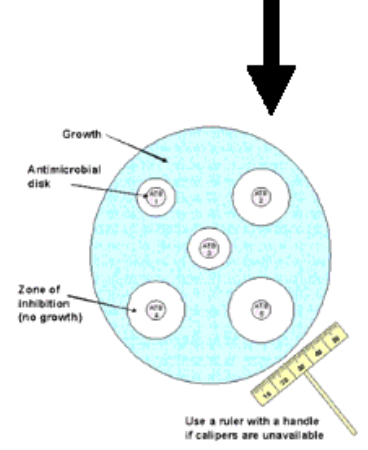

Drug Susceptibility Testing

\section{Figure 2}

The experimental scheme of the study. Milk samples were aseptically collected from bovine with subclinical mastitis and plated onto trypticase soy agar (TSA) plates supplemented with $5 \%$ (vol/vol) defibrinated sheep blood. The staphylococci were then selected for further identified by Vitek 2 system with Gram positive identification card (GPI; bioMerieux Vitek); their antibiotic susceptibilities were detected by the disk diffusion method, and the resistance genes were revealed by PCR assay. 